\title{
Wastewater Treatment for a Coffee Processing Mill in Nicaragua: A Service-Learning Design Project
}

\author{
Michael D. Marsolek \\ Assistant Professor \\ Civil and Environmental Engineering \\ Seattle University \\ marsolem@seattleu.edu \\ Joshua T. Alcantara \\ BS Candidate \\ Civil and Environmental Engineering \\ Seattle University \\ Josh.Alcantara@gmail.com \\ Luis F. Quintero \\ BS Candidate \\ Civil and Environmental Engineering \\ Seattle University \\ luisquintero2@me.com \\ Charles F. Jackels \\ Professor \\ Computing and Software Systems \\ University of Washington - Bothell \\ jackels@u.washington.edu
}

\author{
Patrick K. Cummings \\ BS Candidate \\ Civil and Environmental Engineering \\ Seattle University \\ patrickc@seattleu.edu \\ Michael Wayne \\ BS Candidate \\ Civil and Environmental Engineering \\ Seattle University \\ mikolwin@yahoo.com \\ Carlos Vallejos \\ Coordinator of Natural Sciences \\ Faculty of Science, Technology, and Environment \\ University of Central America - Managua \\ carlosv@ns.uca.edu.ni \\ Susan C. Jackels \\ Professor \\ Department of Chemistry \\ Seattle University \\ sjackels@seattleu.edu
}

Abstract - An undergraduate capstone design project team consisting of candidates for the BS degree in Civil and Environmental Engineering and faculty designed a wastewater treatment facility for a coffee processing mill in rural Nicaragua. The team visited Nicaragua to interview the client community, survey the actual site, and hold discussions with local development agencies, agricultural cooperatives, and potential contractors. Three alternative designs were developed, and the community chose one involving a settling basin and a series of three infiltration pits. The treatment system is expected to meet MARENA discharge standards for $\mathrm{pH}$, turbidity, and chemical oxygen demand (COD) of discharge wastewater. The project team further secured sufficient funding from Tetra Tech, an environmental consulting firm, to build the coffee mill and the water treatment facility. On a subsequent visit, the mill and treatment facility were seen to be well constructed and functional. Several important lessons regarding international service learning design projects were learned: the need for a large cost overrun buffer; the utility of having contributors on-site during both important decision making stages and construction; the value of working with local organizations to facilitate remote work projects; the possibility of private sponsorship and partnership for charitable projects; and the need to work with the community to design and select appropriate technologies.

Index Terms: green coffee, coffee processing, wastewater treatment, engineering design, service learning 


\section{INTRODUCTION}

Strongly fluctuating world market prices for green coffee have long posed difficulties for small-scale coffee producers in developing nations. Over the period 1970-2010, for example, world coffee prices varied greatly, with the annual average ICO Composite Indicator Price fluctuating ${ }^{1,2}$ between an all-time high of $\$ 2.29 /$ lb in 1977 to less than $\$ 0.46 /$ lb in 2001. After languishing well below $\$ 0.60 /$ lb during the early 2000 s, it only rose to above $\$ 2 / \mathrm{lb}$ during $2011^{\mathrm{i}}$. The period during the early 2000 s, when coffee prices were very low, became known as the "Coffee Crisis". 3

One response to the widespread economic displacement and poverty of the Coffee Crisis was to emphasize production of higher quality coffee that also bore international certifications such as Fair Trade and Organic. Success in these specialty markets, drawing prices as much as $40 \%$ above those of the commodity markets, required progress in two areas: 1) Adaptation of farms and methods to comply with the requirements of the desired certifications; and 2) Production of coffee of sufficiently high quality that it will be purchased. Certification alone does not guarantee sale on the specialty market.

At its best, the traditional Nicaraguan process (described below) is capable of producing truly fine gourmet coffees. $^{4}$ To successfully participate in the specialty market, farmers realized that they needed to raise the level of, and minimize the variation in, the quality of their coffee. Development agencies worked with the agricultural communities to improve coffee quality as a strategic way to address their poverty; the Quality Coffee Program of USAID ${ }^{5}$ represented one of these efforts. There are a number of studies assessing the overall success of these specialty certification initiatives. $6,7,8$

The design project described in this paper arose as part of Coffee for Justice, a project initiated at Seattle University by one of the authors (SCJ) in collaboration with her American and Nicaraguan partners and their students. In response to the Coffee Crisis, the mission of Coffee for Justice was to place scientific and technical expertise in service to the small-scale Nicaraguan coffee producer. A discussion of the establishment of Coffee for Justice as an effective program and a review of the outcomes achieved prior to those described here has been accepted for publication elsewhere. ${ }^{9}$ The results of applied chemistry studies conducted in a field laboratory and by the producers on their farms have also been reported. ${ }^{10,11}$

In order to engage the coffee farmers through their organizations and listen carefully to the questions and requests that they might have for us, a process of gradual engagement, as described in Reference 9, was undertaken that began by working through development organizations and agencies such as USAID ${ }^{\mathrm{ii}}$ and $\mathrm{CRS}_{\mathrm{N}} \mathrm{NI}^{\mathrm{iii}}$, then progressing on to regional agricultural cooperatives such as ADDAC ${ }^{\mathrm{iv}}$ and CECOSEMAC ${ }^{\mathrm{v}}$, and finally to individual communities and farmers. Through this network of trusted contacts we were able to learn what was wanted by the farmers and their organizations and to gain access to the farms in order to study their processes.

\footnotetext{
${ }^{\mathrm{i}}$ These historical prices are not adjusted for inflation.

${ }^{\text {ii }}$ United States Agency for International Development

iii Catholic Relief Services - Nicaragua

${ }^{\text {iv }}$ Asociación para la Diversificación y el Desarrollo Agrícola Comunal (Association for Diversification and Development of the Agricultural Community), Matagalpa, Nicaragua.

${ }^{v}$ Central de Cooperativas de Servicios Multiples Aroma del Café, a union of agricultural cooperatives in Matagalpa, Nicaragua
} 


\section{Coffee Processing in Nicaragua}

Sorting, depulping, fermentation, and drying

The local practice in coffee production involves hand-picking of ripe coffee cherries, followed within a few hours by manual selection to eliminate defects and mechanical depulping, all taking place on the farm. After the exocarp (skin) and mesocarp (pulp) of the ripe coffee cherry are eliminated by depulping, the coffee beans retain a sticky, firmly attached mucilage layer that must be removed prior to drying and storage. The mucilage-coated beans are generally placed in an open tank, where natural fermentation is allowed to proceed for 10-48 hours, depending on weather, altitude, etc. At some point (termed "completion") the fermentation process has loosened the mucilage from the bean surface, such that it can then be washed away with water, a process that halts the fermentation and thoroughly cleans the beans.

The clean beans are moved to a patio on the farm, where they are sun-dried to approximately $40 \%$ water content. In most cases, they are then sacked and quickly transported to "dry mills" in hotter and drier locations at lower elevation. After further sun-drying to approximately $12 \%$ water content, the beans are sufficiently stable for storage prior to export as green coffee.

\section{On-farm mill or beneficio}

Coffee producers carry out the steps described above on the farm in a "wet mill" facility known as a beneficio $^{v i}$. This well ventilated, sheltered space, which contains the depulping machinery, fermentation tanks, and washing trough requires a plentiful source of clean water, both to convey the cherries and beans within the mill and to wash them thoroughly. Disposal of a large amount of wastewater, which is heavily laden with carbohydrates and other nutrients from the depulping and washing must also be provided by the beneficio.

In small communities, immediate neighbors may share a beneficio by coordinating their picking and processing schedules. The least advantaged communities sometimes lack even this basic shared processing facility, often resorting to the use of woven plastic sacks for fermentation and improvised washing methods in tubs. Without a clean and well ventilated beneficio, producers cannot be expected to produce coffee of the highest quality.

\section{Wastewater Treatment}

The process described above includes discharge of large amounts of wastewater ${ }^{12}$ resulting from the various processing steps: sorting of cherries by flotation; pulp removal; and washing of the beans after fermentation is complete. Overall, this water is acidic, deoxygenated, and laden with suspended solids and organic material from the pulp and mucilage. ${ }^{13}$ In many traditional beneficios, the wastewater is simply discharged into the nearest stream or river, with considering environmental consequence.

\footnotetext{
vi "Beneficial mill" in Spanish
} 
Modern, "ecological" designs (beneficio ecologico) both reduce the overall water requirement and provide treatment of the wastewater before discharge. The reduction in volume is largely achieved by using pulpers designed to operate with less flowing water and by designing the mill to require less water for transport of the cherries and beans between stages. The remaining water, largely from the washing stage, is then usually treated in a set of settling pits before infiltration into the soil or discharge into the surface waters. On the smaller farms, these pits are often dug without any formal design, and the water usually receives no pre-treatment before discharge into them. In the most advanced installations, generally found only on the largest of haciendas, the treatment of the wastewater may include carefully designed anaerobic digestion with capture of biogas gas for farm fuel.

The stream discharge of polluted wastewater degrades the overall environment of the farm and the water quality for down-stream neighbors, which affects drinking water, sustenance crops, and livestock. Also, some desired certifications ${ }^{14,15}$ require that waste water receive at least minimal treatment before discharge. In our conversations, the small-holder farmers were often interested in appropriate treatment of their wastewater, provided that treatment was neither too expensive nor too difficult to implement and maintain.

\section{Design Project BaCkground}

In a spring 2007 meeting with the leadership of the agricultural cooperative CECOSEMAC, we were informed that a member community at La Suana possessed the potential for excellent coffee, but lacked the basic beneficio needed for well-controlled, high-quality, on-farm depulping and fermentation. This community possessed strong leadership, excellent coffee growing conditions, a good water supply, a site suitable for a beneficio, and a desire to treat their wastewater in an environmentally appropriate manner. This community need for a beneficio was well suited for a service-learning capstone design project for a team of environmental engineering majors in collaboration with the Coffee for Justice Project and the Seattle University Science and Engineering Project Center. The resulting project, Wastewater Treatment Design for a Coffee Processing Beneficio ${ }^{16}$ was accomplished as a capstone design project by a team of four BS in Civil and Environmental Engineering students during the 2007-8 academic year.

\section{PlanNing ANd REQuirements Gathering}

\section{Preliminary Visit}

It was decided during a preliminary visit by the faculty leadership in spring 2007 that the student team would focus only on design of the wastewater treatment facility, with the design of the beneficio building and construction of the entire facility to be accomplished by a small contractor familiar to CRS and CECOSEMAC. It became apparent that this project would be different than the ordinary Project Center capstone in a number of ways:

1. The project client was a poor rural community in Nicaragua that did not have resources to fund it. Normally, the industrial sponsor funds the project and serves as its client. 
2. The client interviews and site assessment necessary for requirement gathering would require the team to visit the rural community at La Suana. This would involve international travel, the transport of field survey and test equipment, and the presence of someone with adequate language skills.

3. The student team would see the project through to implementation and evaluation. Normally designs resulting from completed student projects are delivered to the sponsor, with subsequent implementation of the design being the prerogative of the client. By involvement in implementation, the service-learning project goes beyond the theoretical and offers a greater opportunity for professional service and development.

Funding available for the project would need to be adequate not just for the design phase, but also for the construction of the entire beneficio and water treatment facility. And, since significant funding was to be expended in Nicaragua, the team needed to establish a mechanism for responsible remote project management and expenditures. This project management was complicated by the fact that none of the team could be present on-site during the construction phase.

\section{Full Team Visit}

The faculty and the four-member student team visited Matagalpa, Nicaragua in December 2007. They toured and observed several functioning beneficios, including measurements of the volume and quality of wastewater (see Figure 1) at the ADDAC model farm La Canavalia.

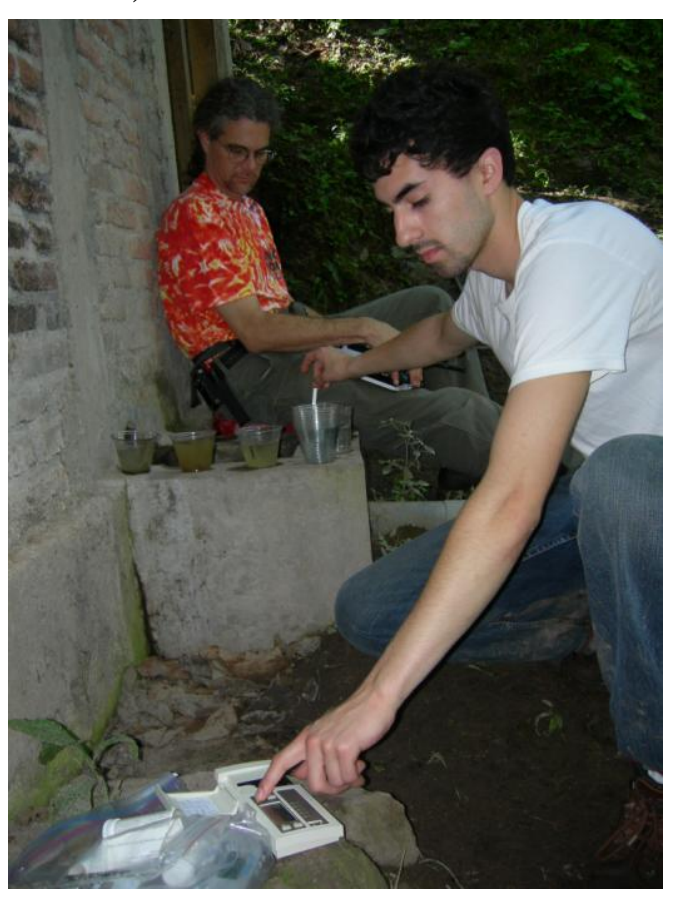

FIGURE 1

WaStewater Quality MEASUREMENTS AT La CANAVALIA 
International Journal for Service Learning in Engineering

Vol. 7, No. 1, pp. 69-92, Spring 2012

ISSN 1555-9033

This beneficio utilized an ad hoc system of three settling pits to provide water improvement through filtration, neutralization, and microbial decomposition of organic material before infiltration to the nearby stream.

Subsequently, the student team interviewed the client community at La Suana and went to the proposed site, carefully surveying it and determining that there was suitable land for both the mill and adjacent water treatment options (see Figure 2). Working with the staff of CECOSEMAC and CRS-NI, the team identified a contractor with the necessary expertise to build the water diversion/storage structure, the wet mill, and the water treatment option that would be selected by the community. The initial construction time line and cost estimates were established for construction to be completed prior to November 2008, the start of the next harvest season (see Figure 3).

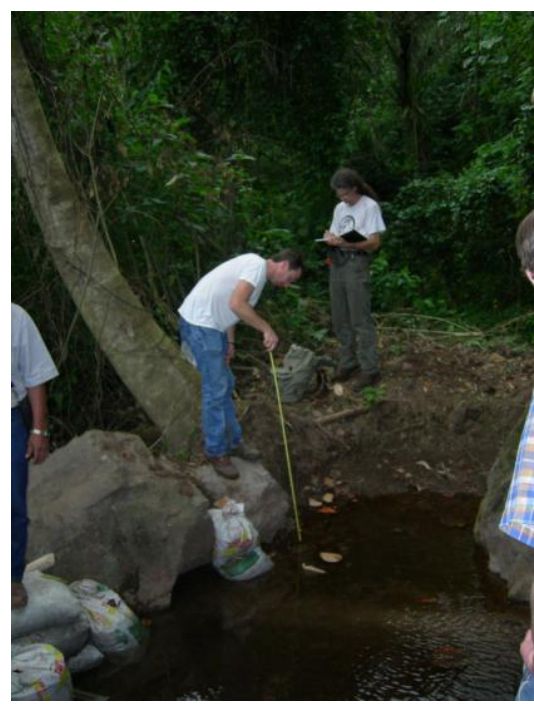

FIGURE 2

Site ASSESSMENT AT LA SUANA

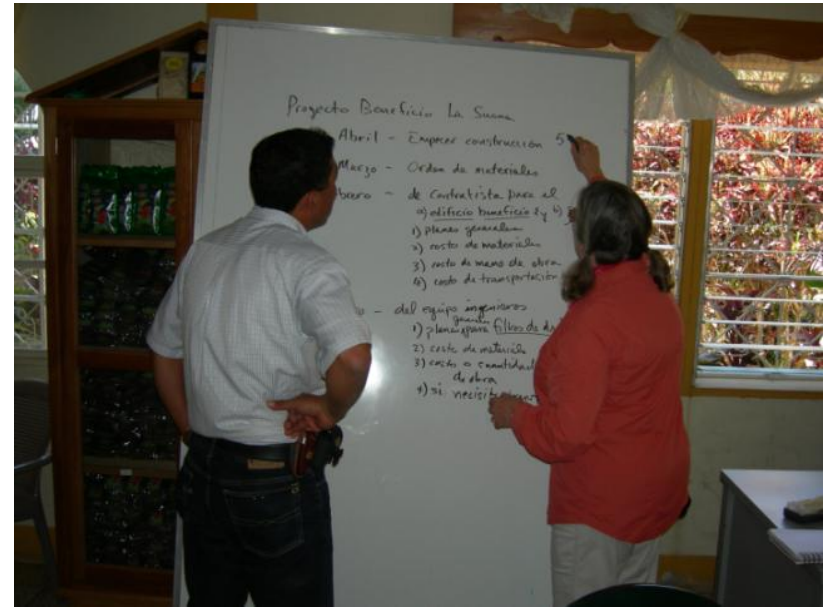

FIGURE 3

PROJECT PLANNING WITH

CECOSEMAC 
Upon returning to Seattle in December 2007, the team established a set of goals:

- design a set of wastewater treatment options to be presented to the client community in late winter or early spring of 2008;

- work with the community at long range to select an option and finalize the design with the contractor;

- establish a mechanism to both disburse funds to the contractor as he completed phases of the project and keep the project on track for completion prior to October 2008, and;

- construct the beneficio prior to the 2008 harvest season in the dry season when roads are passable.

Trusted Coffee for Justice contacts in Nicaragua (staff and leadership at CRS-NI and CECOSEMAC) agreed to serve as on-site observers and as our representatives.

\section{Project Constraints}

The team identified several project constraints:

1. Capacity: The beneficio and water treatment facility must meet the processing requirements of five families and meet or exceed regional standards for high quality coffee.

2. Water Conservation: The process steps must be designed to minimize water usage, particularly in the transport and mechanical pulping of the coffee cherries.

3. Sustainable and Organic Standards: The entire design must be compatible with sustainable and organic standards as required by the local farmer's cooperative CECOSEMAC and by the Nicaragua Fair Trade program. For discharge to surface waters, the wastewater effluent must meet or exceed standards of the Ministerio Del Ambiente y Los Recursos Naturales de Nicaragua (MARENA).

4. Electrical Power: The location does not have access to electricity.

5. Limited Footprint: The wastewater treatment system adjacent to the beneficio must occupy the space available between the existing road and hill, currently a drainage route approximately $3 \mathrm{~m}$ wide and $70 \mathrm{~m}$ long.

6. Geotechnical Considerations: The road leading up to the site is in poor condition and will not permit large equipment or delivery trucks. Impact on the stability of the existing road was considered in the alternatives.

7. High Strength Wastewater: The wastewater is high strength with respect to BOD/COD content, nutrient concentration, and suspended solids. It also has a low dissolved oxygen (DO) concentration.

8. Low $\mathrm{pH}$ : The wastewater is very acidic and must be neutralized to avoid ecological and concrete deterioration.

9. Construction Materials: Materials commonly available in the region include but are not limited to concrete, plastic liner, gravel, PVC pipe, and wood. 


\section{Preliminary AsSessments}

\section{Site Assessment}

La Suana is located in the municipality of San Ramon $\left(12^{\circ} 55^{\prime}\right.$ north latitude and $85^{\circ} 50^{\prime}$ west longitude). The climate is of sub-tropical rainforest with average temperature between $20^{\circ}$ and $26^{\circ} \mathrm{C}$ and annual rainfall between 2000 to $2400 \mathrm{~mm}$. The site was surveyed using hand held equipment, and a planview of the area available for wastewater treatment (Figure 4) shows that it is to be located in a ditch on a hillside adjacent to a road or path. The ditch is approximately 10 feet wide (opposing arrows in Figure 4) and 220 feet long, for an area $2200 \mathrm{ft}^{2}\left(200 \mathrm{~m}^{2}\right)$. The adjacent road is $15-100$ meters from the nearby stream.

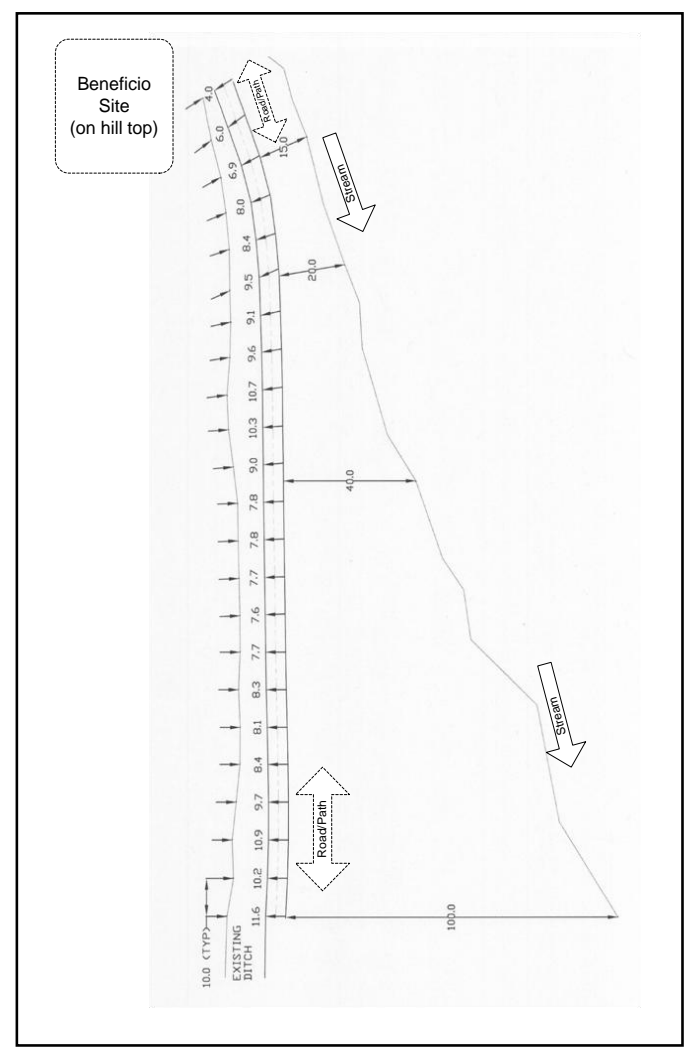

FIGURE 4

\section{PLAN VIEW OF THE DRAINAGE DITCH ALONG WITH SITE MEASUREMENTS}

In Figure 5 is a picture of the site, looking from top to bottom, an orientation opposite to that of the plan-view map. In the picture, the stream is down hill to the left, the drainage ditch is to the right of the path, and the site of the beneficio is in the field to the right. 


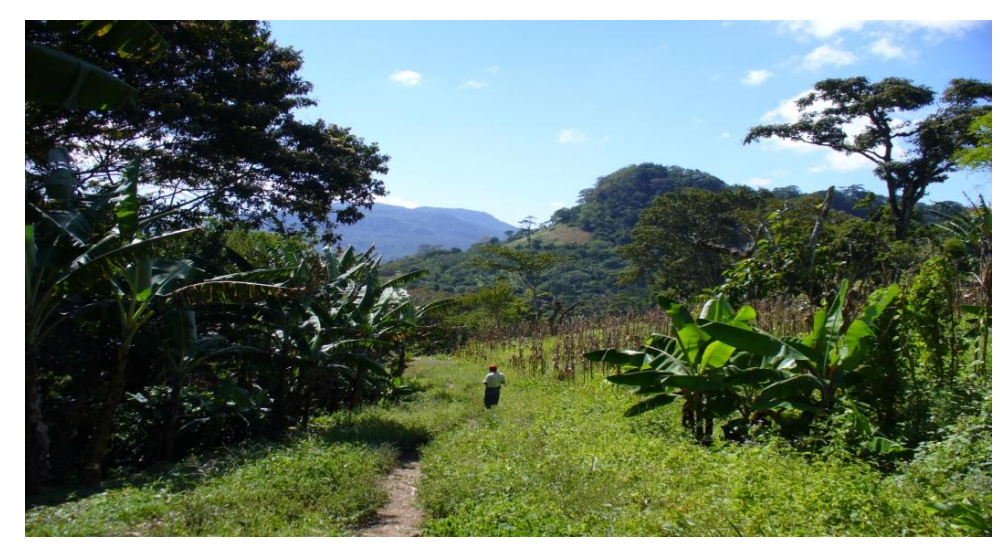

FIGURE 5

VIEW OF ROAD AND DRAINAGE DITCH FROM TOP TO BOTTOM

\section{Soil Assessment}

A grab sample of soil was taken one foot below the surface and qualitatively observed to be a dark brown silty fat clay soil with a high organic content. Due to time constraints, the design team was unable to generate reproducible and reasonable soil infiltration rate data via standard percolation tests, and detailed soil survey data was unavailable for this region. Therefore, Natural Resource Conservation Service ${ }^{17}$ data $^{1}$ for Puerto Rico was used for representative soil profiles selected based on the five soil forming factors: parent material, topography, biota, time, and climate. Three representative soil series chosen (Aibonito, Lirios, and Cortada) are all clay/silt dominated soils derived from volcanic rock parent material and exist on 20-40 percent slopes in mountainous regions receiving approximately 70-90 inches of annual rainfall at an average annual temperature of $75^{\circ} \mathrm{F}$. These soils formerly supported rainforest and are now used to cultivate shade-grown coffee. The reported permeability (velocity) for each of these soils at depths less than 30 inches is 0.6 to $2 \mathrm{in} / \mathrm{hr}^{18,19}$

\section{Wastewater Analysis}

To characterize the wastewater anticipated at La Suana during its operation, measurements were done on the effluent from the operating beneficio at La Canavalia, which utilizes a system of three open infiltration pits in series. Measurements of chemical oxygen demand (COD), $\mathrm{pH}$, turbidity, and dissolved oxygen (DO) were made at the following locations: the fresh water source; the river above and below the beneficio; the depulping wastewater; the rinse wastewater; entrance to each of the three infiltration pits, and the infiltration effluent near the river. The depulping- and rinsing wastewater are produced at different times, but reside in pit \#1 long enough to thoroughly mix. The wastewater overflows from pit \#1 in turn into pits \#2 and 3.

Sampling was done at intervals throughout the rinsing process, which can take from 0.5 to 3 hours, and a representative sample was created by combining the range of interval samples. The samples for COD measurement were collected in $2 \mathrm{ml}$ vials that were frozen and returned to Seattle University for analysis (Chemetrics high-range COD vials \& HachDRB200 Digital Reactor Block). The pH was determined using a battery operated colorimetric reader for test strips (ReflectoQuant). The turbidity was determined using a 
Turbidity meter on site (Hach DR/820 Colorimeter). The DO was determined using a DO Probe (Vernier Dissolved Oxygen Probe).

The depulping and rinsing processes produce wastewater with different characteristics, with the depulping waste being higher in dissolved organics but less acidic. Being of an "ecological" design, the new beneficio at La Suana should produce relatively less depulping wastewater, and a conservative set of design parameters were determined by taking volume-weighted averages of the rinse (80\%) and depulping $(20 \%)$ wastewater measurements at La Canavalia (Table 1).

TABLE 1

MEASURED WASTEWATER CHARACTERISTICS

\begin{tabular}{ccccc}
\hline Parameter & $\begin{array}{c}\text { Rinse } \\
\text { Wastewater }\end{array}$ & $\begin{array}{c}\text { Depulping } \\
\text { Wastewater }\end{array}$ & $\begin{array}{c}\text { Design } \\
\text { Parameters }^{\dagger}\end{array}$ & $\begin{array}{c}\text { Upstream } \\
\text { River }\end{array}$ \\
\hline $\mathrm{COD}(\mathrm{mg} / \mathrm{L})$ & 5500 & 7246 & 5850 & 54 \\
$\mathrm{pH}$ & 4.4 & 5.1 & 4.5 & 5.2 \\
$\mathrm{DO}(\mathrm{mg} / \mathrm{L})$ & $<1$ & $<1$ & 1 & N/A \\
Turbidity (NTU) & 480 & 760 & 540 & 31 \\
\hline
\end{tabular}

${ }^{\dagger}$ Assuming $80 \%$ rinse- and $20 \%$ depulping waste.

Based on water volume measured at La Canavalia and conversations with the producers at La Suana, it was estimated that the new mill would produce a peak wastewater volume of $9 \mathrm{~m}^{3} /$ day, for a daily coffee bean production of 12 quintales (qq). ${ }^{\text {vii }}$

Assuming $2.75 \mathrm{qq}$ of cherries yields $1 \mathrm{qq}$ of processed coffee beans ${ }^{13}$, this estimate would be approximately $6 \mathrm{~m}^{3}$ water per tonne of coffee cherry, which is at the low end of the range cited in Ref. 13 $\left(4-20 \mathrm{~m}^{3} / \mathrm{t}\right)$. This estimate was considered reasonable for a modern "ecological" beneficio.

In order to model the removal efficiency of the primary sedimentation pond in subsequent designs, water quality was measured at La Canavalia in triplicate at four depths in infiltration pit \#1 (2", 7", 11", 14.5”). As shown in Figure 6, turbidity increases 6-fold from a depth of 2 to 14 in, and COD increases 2.5fold. The DO and $\mathrm{pH}$ remain relatively constant $(1 \mathrm{mg} / \mathrm{L}$ and 4.2 , respectively) throughout pit \#1.

\footnotetext{
vii 1 quintal (qq) $=100 \mathrm{lb}=0.0454$ tonne.
} 


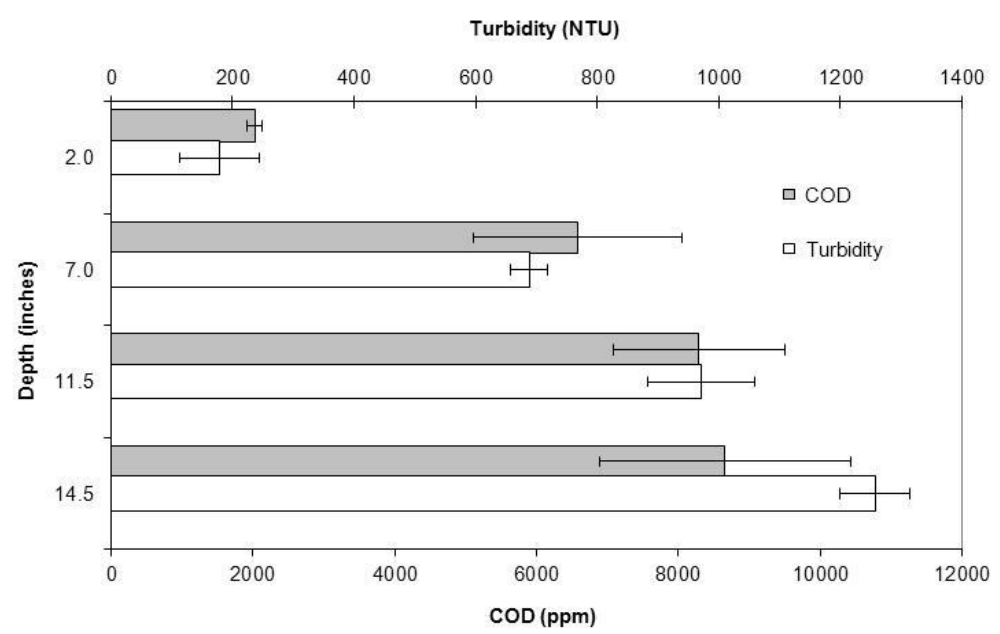

FIGURE 6

COD AND TURBIDITY AS A FUNCTION OF DEPTH IN PIT \#1 FROM TOP TO BOTTOM

To assess the treatment capability of a series of infiltration pits, data was collected at various stages within the wastewater treatment process. When compared, this data (Table 2) shows that pit \#1 is effective in removing about 55\% of the COD and turbidity and that seeping infiltrate (through soil) further demonstrates a very large improvement in $\mathrm{pH}$. There is little further improvement in COD in pits 2 and 3 , in large part because the $\mathrm{pH}$ in pits 2 and 3 remains too low to facilitate the growth of the necessary anaerobic microorganisms

for

biodegradation.

TABLE 2

WASTEWATER CHARACTERISTICS AT LA CANAVALIA INFLITRATION PITS

Grab Sample $\quad$ COD $(\mathrm{mg} / \mathrm{L}) \quad \mathrm{pH} \quad$ Turbidity (NTU)

\begin{tabular}{llll}
\hline Influent to Pit $1^{\mathrm{a}}$ & 5850 & 4.5 & 604 \\
& & & \\
Influent to Pit $2^{\mathrm{b}}$ & 2660 & 4.1 & 233 \\
${\text { Influent to Pit } 3^{\mathrm{b}}}_{\text {Infiltrate through soil }^{\mathrm{b}, \mathrm{c}}}^{2170}$ & 4.1 & 270 \\
\hline
\end{tabular}

${ }^{a}$ Design parameter weighted average of rinse (80\%) and depulping (20\%) wastewater

${ }^{\mathrm{b}}$ Measured

${ }^{\mathrm{c}}$ Hillside seepage, 15-20 feet from the infiltration pits 


\section{WaStewater Treatment DeSign Alternatives}

The entire wastewater treatment system will occupy a drainage route of $200 \mathrm{~m}^{2}$ (see Figs 4 and 5) that maintains a grade of approximately $10 \%$. The designs are sized to accommodate an average daily volume of approximately $9 \mathrm{~m}^{3}$, a maximum effluent rate of $1 \mathrm{~L} / \mathrm{s}\left(0.001 \mathrm{~m}^{3} / \mathrm{s}\right)$, and influent COD concentration of $5850 \mathrm{mg} / \mathrm{L}$ (Table 2). The design parameters for wastewater characteristics, flow rates, and residence times of the treatment facility conservatively achieve an overall "safety factor" of approximately two. All treatment alternatives are intended to meet the 1995 MARENA standards ${ }^{20}$ for surface water discharge.

For the purposes of using empirical design equations, the design COD was converted to $\mathrm{BOD}_{5}$. The $\mathrm{BOD}_{5} / \mathrm{COD}$ ratio of the wastewater is estimated to be 0.60 . This value is obtained by weighting the $\mathrm{BOD}_{5} / \mathrm{COD}$ ratios reported by Deepa et $\mathrm{al}^{21}$ for rinse and depulping coffee wastewater with the same volume ratio used for design parameters in Table 1. This yields a design parameter in terms of $\mathrm{BOD}_{5}$ of $3510 \mathrm{mg} / \mathrm{L}$.

The team produced three alternative designs, each with a three stage process:

- Primary treatment in a settling basin with $\mathrm{pH}$ neutralization (common to the alternatives);

- Secondary treatment in an anaerobic process unique to each alternative; and

- A finishing step by either subsurface infiltration (Alt 1) or overland flow (Alts $2 \& 3$ ).

Common to the three alternatives and described below are: a) a fresh water valve; b) simple concrete pad for neutralizing wastewater and screening coffee beans from it; and c) a primary settling basin (i above).

TABLE 3

MARENA SURFACE WATER DisCHARGE REGULATIONS

\begin{tabular}{ll}
\hline \hline Parameter & Allowed range \\
\hline BOD & $<120 \mathrm{mg} / \mathrm{L}$ \\
COD & $<200 \mathrm{mg} / \mathrm{L}$ \\
pH & $6.5-9$ \\
TSS & $<150 \mathrm{mg} / \mathrm{L}$ \\
Settleable Solids & $<1.0 \mathrm{ml} / \mathrm{L}$ \\
Fats and oils & $<10 \mathrm{mg} / \mathrm{L}$ \\
\hline \hline
\end{tabular}

*MARENA 1995 (See Ref. 20) 
Freshwater Valve

A 3-inch PVC pipe brings water to the site from a makeshift sandbag dam and pond at a rate of $1.3 \mathrm{~L} / \mathrm{sec}$. Water conservation can be accomplished through installation of a simple ball valve that regulates flow up to the max requirement of the operating beneficio $(1 \mathrm{~L} / \mathrm{sec})$.

\section{Neutralization}

To provide an optimal $\mathrm{pH}$ range (6.5-7.7) ${ }^{22}$ for biodegradation of the nutrients by diverse microbial populations, the wastewater will be neutralized from an initial $\mathrm{pH}$ of 4.2 to approximately $\mathrm{pH} 7$. Neutralization of the wastewater, which is to be used for irrigation (Alternatives 2 and 3), will also promote healthy soils and robust vegetative growth. ${ }^{23}$ Beneficio workers will be asked to throw calcium oxide (locally available as "cal") onto the concrete slab where the rinse water is channeled enroute to the treatment system. Assuming the "cal" will have hydrated to $\mathrm{Ca}(\mathrm{OH})_{2}$ during storage, the stoichiometric amount can be provided using a container marked to hold approx $34 \mathrm{~cm}^{3}$.

\section{Primary Settling Basin}

Common to the three alternatives is a primary treatment settling basin with the following characteristics:

- A volume of approximately $10.8 \mathrm{~m}^{3}$;

- Lining to prevent direct soil infiltration, and;

- A hydraulic retention time of approximately three hours, a value based on typical settling times for agricultural wastewaters of 3-6 hours. ${ }^{24}$

These parameters are based on the beneficio flow rate $(1 \mathrm{~L} / \mathrm{s})$ and daily operating cycle $(<3 \mathrm{~h})$. In practice, since the mill is used only once each day, the wastewater will have a residence time of approximately eighteen hours before flowing from the settling basin to an anaerobic biodegradation stage for further COD/BOD reduction.

For mosquito control, the settling basin should be covered with staggered wire-mesh window screens. By staggering the typically available $18 \times 16$ mesh (1.0x1.2 mm squares), the hole size can be halved to less than $1 \mathrm{~mm}$ in both directions $(0.5 \times 0.6 \mathrm{~mm})$, preventing passage of even the smallest mosquitoes. While the hole size in unstaggered 18x16 mesh is deemed acceptable by the $\mathrm{WHO}^{25}$, for Anopheles control via bednets, a study by Bidlingmayer ${ }^{26}$ (1959) found that dengue vectors, Aedes aegypti and Aedes taeniorhynchus, passed through an 18x14 mesh copper screen $1.5 \%$ and $26 \%$ of the time respectively, compared to only $0.1 \%$ and $0.6 \%$ when using a $22 \times 22$ mesh fiberglass screen ( $0.8 \mathrm{~mm}$ diameter holes). Because dengue is a concern in the region, and the staggering of common window screens is easy, our recommendation is to employ them to cover the surface of the settling basin. It should be noted that even if the low $\mathrm{pH}$ wastewater during harvest season precludes mosquito larvae growth, accumulation of rainwater at other times of the year still necessitates covers. 
Building upon the common elements described above, the team developed three alternative designs for anaerobic secondary treatment and finishing steps.

1. Three infiltration pits with subsurface infiltration.

2. Horizontal-flow anaerobic basin; surface discharge and infiltration.

3. Upflow anaerobic sludge blanket; surface discharge and infiltration.

The first two were considered very practical for the community, and the third one was provided to illustrate the small-community implementation of a state-of-the-art technology.

\section{Design Alternative 1}

A sketch of the overall design is shown in Figure 7. The settling basin in this design is lined with HDPE plastic and has dimensions of $1.5 \mathrm{~m}(\mathrm{w}) \times 1.5 \mathrm{~m}(\mathrm{~d})$ × $6 \mathrm{~m}(\mathrm{l})$, with 2:1 (V:H) side slopes to provide stability in the absence of concrete. The bottom of the basin has a 1:16 slope to encourage settling near the input pipe. ${ }^{22}$

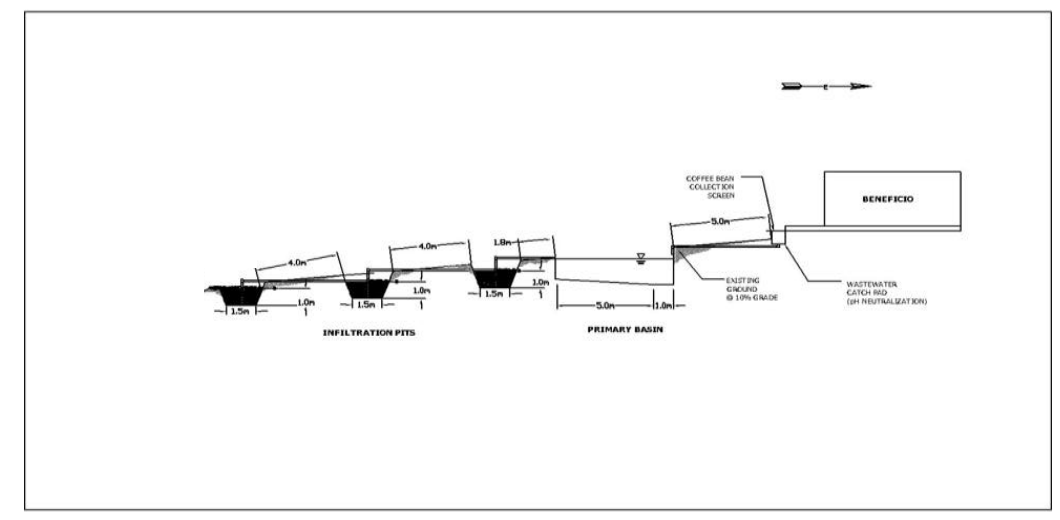

FIGURE 7

PRIMARY BASIN \& INFLITRATION PITS (ALt \#1)

After primary treatment in the settling basin, the wastewater flows out over a V-notch weir wall and is gravity fed into three parallel rock-media infiltration pits, characterized as follows:

- Dimensions: $1.5 \mathrm{~m}$ by $1.5 \mathrm{~m}$ at a depth of $1 \mathrm{~m}$; Side slopes 3:1 (V:H),

- Volume approx $3.4 \mathrm{~m}^{3}$, in accord with the recommendation of the King County Surface Water Treatment Manual 2005 ${ }^{27}$,

- Rocks are $10 \mathrm{~mm}$ in diameter, and vertical filling pipes have smaller holes,

- Covered with framed and staggered window screens (see Settling Basin above). 
The rock media provides a growth surface for the microorganisms, helps distribute the water throughout the pit at low flow rates, and reduces the danger from falling into the pits. Organic material will biodegrade similar to being in a subsurface flow wetland as defined by the EPA. Based on the measured COD reduction from settling in Tables 1 and 2, the $\mathrm{BOD}_{5}$ of the effluent from the settling basin to the first pit is modeled to be $45 \%$ of the design influent, or $1580 \mathrm{mg} / \mathrm{L}$. $\mathrm{BOD}_{5}$ biodegradation in the pits is modeled via first order kinetics $\left(\mathrm{k}=1.104 \mathrm{~d}^{-1}\right)^{28}$ and time weighted average of $12 \mathrm{~h}$, for a further reduction of $42 \%$. The infiltrate from these pits into the subsurface should have a $\mathrm{BOD}_{5}$ of approximately $910 \mathrm{mg} / \mathrm{L}$, a reduction of $74 \%$ before soil infiltration. In comparison, first-order biodegradation in an anaerobic fixed film process operates with a rate constant of $10.3 \mathrm{~d}^{-1}$ for wastewater containing carbohydrates and protein, ${ }^{29}$ making the present value very conservative.

Physical filtration by soil can remove a broad range of $\mathrm{BOD}_{5}$, reported from 30-40 percent by Gohil $^{30}$ (p. 36), to 86-100 percent for a number of rapid infiltration systems. ${ }^{31}$ It should be noted that rapid infiltration systems typically have lower BOD loading rates than the infiltration pits, and these results use domestic wastewater. As a conservative estimate, it is assumed that $30 \%$ of the BOD is removed via soil filtration, yielding a $\mathrm{BOD}_{5}$ concentration of $640 \mathrm{mg} / \mathrm{L}$ entering the subsurface.

To estimate $\mathrm{BOD}_{5}$ reduction due to biodegradation in the subsurface, a first-order constant ${ }^{32}$ of $0.0127 \mathrm{~d}^{-1}$ is used. This constant applies to biodegradation of aromatic hydrocarbons in northern Minnesota, and is therefore likely to be conservative. Biodegradation time is estimated with hydraulic conductivity and soil porosity. Since only feasible on-site analysis was a qualitative determination that the soil is a silty-clay, an exact hydraulic conductivity and porosity could not be determined. The range of typical hydraulic conductivities for clay is $1 \times 10^{-5}-1 \times 10^{-7}$ $\mathrm{m} / \mathrm{s} .{ }^{33}$ Porosity of clay/silt soils typically range over $50-60 \% .{ }^{33,34}$ Combining these numbers, the expected residual $\mathrm{BOD}_{5}$ reaching the river approximately $40 \mathrm{~m}$ away at the system midpoint would range from $0 \mathrm{mg} / \mathrm{L}$ with $\mathrm{K}=1 \times 10^{-7} \mathrm{~m} / \mathrm{s}$, to $460 \mathrm{mg} / \mathrm{L}$ with $\mathrm{K}=1 \times 10^{-5} \mathrm{~m} / \mathrm{s}$. Using the intermediate hydraulic conductivity, $\mathrm{K}=1 \times 10^{-6} \mathrm{~m} / \mathrm{s}$, results in an estimated residual $\mathrm{BOD}_{5}$ concentration of $25 \mathrm{mg} / \mathrm{L}$. This number is used for future analysis.

Alternative \#1, with a total cost for wastewater treatment of \$787 US, meets all of the design constraints and the MARENA standards for surface water discharge. ${ }^{\text {vii }}$ Although similar in its design to others used in the region, the plastic lined settling basin and the use of "cal" for neutralization will improve performance dramatically. The operation and maintenance implications are: daily addition of "cal"; periodic removal of sludge from settling basin; and renewal of the plastic liner, perhaps annually. The primary "negative" for alternative \#1 is that it does nothing to remove nitrate from infiltrating wastewater. The phosphorous concentrations will be reduced via soil adhesion, however.

\footnotetext{
${ }^{\text {viii }}$ Provided that hydraulic conductivity $\mathrm{K} \leq 1.9 \times 10^{-6} \mathrm{~m} / \mathrm{s}$.
} 


\section{Design Alternative 2}

In this design, the three infiltration pits of Alternative 1 are replaced by a horizontal-flow anaerobic basin to provide secondary treatment of the effluent from the primary settling basin. Effluent from the anaerobic basin flows on the surface into a hand-excavated shallow sinusoidal channel with a crop such as corn grown between the channel loops. The wastewater will infiltrate the soil from the channel and will not flow overland into the stream.

Since the anaerobic basin will be formed from concrete, the design specifies that the primary settling basin should also be of concrete and attached to it, with the following characteristics:

- Concrete - no further lining required,

- Dimensions: $3.0 \mathrm{~m}(\mathrm{w})$ x $3.8 \mathrm{~m}(\mathrm{l}) \times 1.0 \mathrm{~m}(\mathrm{~d})$,

- Divided into two sections by concrete wall $1 \mathrm{~m}$ from end, with three $10 \mathrm{~cm}$ PVC pipes passing through at $2 / 3$ of full depth.

The concrete settling basin has volume and hydraulic characteristics similar to those of Alternative \#1, but with a different shape. The concrete wall dividing it insures that both the sediment near the bottom and floating mass of organic material near the surface remain in the first section and do not pass through the weir into the anaerobic basin.

Water flows through a simple rectangular weir from the second section of the settling basin into the adjacent anaerobic horizontal-flow attached-growth basin that is filled with sand or gravel to enhance the interaction area between microbes and wastewater. The anaerobic basin is characterized as:

- Dimensions: $2.8 \mathrm{~m}(\mathrm{w})$ x $4.2 \mathrm{~m}(\mathrm{l}) \times 1.2 \mathrm{~m}(\mathrm{~h})$; Volume approximately $14 \mathrm{~m}^{3}$,

- Hydraulic retention time (HRT) of approximately 36 hours,

- Open to atmosphere.

Literature values for up-flow and down-flow anaerobic basins indicate they can accept organic loadings in the range $3000-9300 \mathrm{mg} / \mathrm{L} \mathrm{BOD}_{5}$ and can be expected to reduce it by $75-$ $90 \%$ for HRT's of 18-30 hours. ${ }^{35}$ The combination of unstirred horizontal flow and the extremely low DO of the influent (Table 1

\section{MEASURED WASTEWATER CHARACTERISTICS}

) assure that the basin will remain anaerobic except possibly at the surface. In this horizontal flow case, we are using a conservative estimate of $55 \%$ reduction, which in combination with the $55 \%$ reduction estimated for the settling basin, allows us to estimate the $\mathrm{BOD}_{5}$ of effluent from the anaerobic basin as only $20 \%$ of its initial value $(0.20 \times 3510 \mathrm{mg} / \mathrm{L})$ or $710 \mathrm{mg} / \mathrm{L}$.

The maximum influent $\mathrm{BOD}_{5}$ loading rate recommended ${ }^{35}$ for slow-rate soil infiltration is $0.05 \mathrm{~kg} \mathrm{BOD} 5 / \mathrm{m}^{2}$-day, which yields a maximum of $10.0 \mathrm{~kg} /$ day if the entire ditch $\left(200 \mathrm{~m}^{2}\right.$ in Figure 4) is utilized. This maximum requires that wastewater at peak volume of $9 \mathrm{~m}^{3} /$ day, have its $\mathrm{BOD}_{5}$ loading no more than $1.1 \mathrm{~kg} / \mathrm{m}^{3}$ or $1100 \mathrm{mg} / \mathrm{L}$. The conservative estimate above of 710 $\mathrm{mg} / \mathrm{L}$ for the effluent from the anaerobic reactor is well within this recommendation.

In addition to the reduction of organic components, the phosphorous and nitrogen containing waste components are also of concern for surface disposal. Phosphorous, with estimated 
concentration of $15.8 \mathrm{mg} / \mathrm{L}$ in coffee processing wastewater, ${ }^{13}$ is expected to bind with organic and mineral soil components and not leach significantly through the soil profile. ${ }^{36}$ Nitrogen removal will also occur in the rhizosphere of the overland soil infiltration step. At the daily flow rate above for a maximum of 120 days per year, the expected wastewater concentration of nitrogen $(150 \mathrm{mg} / \mathrm{L})^{13}$ yields an estimated maximum actual rate for nitrogen loading of 0.94 $\mathrm{kg} / \mathrm{m}^{2}$-yr. The acceptable nitrogen level for water leaching into the ground water is $\operatorname{set}^{37}$ at 10 $\mathrm{mg} / \mathrm{L}$ in Washington State and is used as the design standard here. In conjunction with an analysis $^{35}$ for crop uptake, denitrification, and volatilization, this value yields a maximum allowable loading of $1.00 \mathrm{~kg} / \mathrm{m}^{2}-\mathrm{yr}$, which is $6 \%$ greater than the actual maximum loading rate estimated above. Harvest of corn, which is commonly grown in this region, would result in removal of nitrogen and phosphorous from the soil, aiding in the wastewater treatment.

Alternative \#2, with a total cost for wastewater treatment of $\$ 1,506$ US, meets all of the design constraints and the MARENA standards for surface water discharge. Although initially more expensive than alternative \#1, it offers the farmers a simple method of wastewater treatment that would also yield irrigated corn and removal of inorganic nutrients that are left unremediated in alternative \#1. The only regular maintenance would involve removal of sludge from the primary basin and daily addition of "cal" during the coffee harvest period. The "negatives" of this design include greater cost, farmers' resistance to re-using wastewater even for irrigation, and reliance on consistent addition of "cal."

\section{Design Alternative 3}

Alternative \#3 is similar to alternative \#2, except that it uses an upflow anaerobic sludge blanket (UASB) instead of the attached growth anaerobic basin for secondary treatment. Primary treatment would again involve a settling basin as in other designs, and the final disposal would be through an overland channel as in alternative \#2. UASB reactors demonstrate $\mathrm{BOD}_{5}$ reductions of $85-95 \%,{ }^{22}$ and are used in some larger haciendas in the region. Similar to Alternative \#2, this design would meet all performance criteria, including nitrogen and phosphorous removal. Construction would be simple, but would require purchasing a prefabricated UASB. The production of biogas to be used as a fuel is not a compelling attraction at La Suana where the use of the gas in the kitchen would require transporting it some distance across the farm. Also, many of these farms have adequate supplies of fuel wood that is grown for that purpose within the shade canopy of the coffee plantation. Since it can be difficult to restart the UASB reactor, the system must be maintained and supplied biomass year around, posing a significant operational burden for a small community with no beneficio employees. For these reasons, alternative \#3 was presented, but not recommended, and was not given strong consideration by the community. Details of the design are available upon request.

\section{EVALUATION AND RECOMMENDATION}


In May 2008, the student team presented the alternatives to the small producer clients. Due to academic schedule and travel budget constraints, the report, recommendation, and discussion were transmitted electronically rather than presented in person. In Table 4 is outlined a comparison of the two most feasible alternatives with respect to four significant parameters.

Alternative \#1 is an attractive option as it is the least expensive, is a technology familiar to the farmers in this community, and provides good treatment for BOD, $\mathrm{pH}$, and TSS, which are the main pollution concerns. However, it provides no reduction of the high nitrogen content before infiltration to the soil, and relies on subsurface treatment which can be highly variable.

Alternative \#2 involves greater initial expense and poses greater construction challenges due to the materials transport and concrete work to be done on site. However, it provides full treatment of wastewater, including nitrogen and phosphorous removal and provides a useful crop for the farm. Although simple and easy to understand, the overland discharge approach is not as common and familiar to the clients and may not be fully "trusted."

The team recommended Alternative \#2 to the clients, believing that the initially greater expense would be more than compensated for by the improved water treatment quality, the low level of long term maintenance required, and the benefit of the corn crop produced.

TABLE 4

ASSESSMENT OF ALTERNATIVES \#1 AND \#2

\begin{tabular}{|c|c|c|}
\hline & Alternative 1 & Alternative 2 \\
\hline $\begin{array}{l}\text { Performance } \\
\text { BOD }_{5} \text { Reduction } \\
\text { TSS Removal } \\
\text { pH } \\
\text { Nitrogen Removal } \\
\text { Phosphorous } \\
\text { Removal }\end{array}$ & $\begin{array}{l}\text { Exceeds standards }{ }^{\dagger} \\
\text { Exceeds standards } \\
\text { Neutralized to } 7 \\
\text { None } \\
\text { Sedimentation }\end{array}$ & $\begin{array}{l}\text { Exceeds standards } \\
\text { Exceeds standards } \\
\text { Neutralized to } 7 \\
\text { Bioaccumulation } \\
\text { and crop harvest } \\
\text { Sedimentation, } \\
\text { bioaccumulation and } \\
\text { harvest }\end{array}$ \\
\hline $\begin{array}{l}\text { Constructability } \\
\text { Labor } \\
\text { Construction } \\
\text { Delivery of } \\
\text { Materials }\end{array}$ & $\begin{array}{l}\text { Soil excavation and } \\
\text { fill } \\
\text { Simple } \\
\text { Gravel }\end{array}$ & $\begin{array}{l}\text { Soil excavation and } \\
\text { fill } \\
\text { Simple } \\
\text { Cement, sand, and } \\
\text { gravel }\end{array}$ \\
\hline
\end{tabular}




\begin{tabular}{|l|l|l|}
\hline Maintenance & $\begin{array}{l}\text { Sediment removal } \\
\text { Periodic cleaning of } \\
\text { pipe system. }\end{array}$ & $\begin{array}{l}\text { Sediment removal } \\
\text { Corn harvesting }\end{array}$ \\
$\begin{array}{l}\text { Inspection and } \\
\text { replacement of } \\
\text { plastic liner. }\end{array}$ & \\
\hline Cost & $\$ 790$ & $\$ 1,500$ \\
\hline
\end{tabular}

${ }^{\dagger}$ Providing that soil hydraulic conductivity $\mathrm{K} \leq 1.9 \times 10^{-6} \mathrm{~m} / \mathrm{s}$.

\section{Client decision}

The community chose Alternative \#1 largely due to lower construction cost and their familiarity with infiltration-pit technology. It seemed there was resistance to re-using the wastewater for irrigation, since previous attempts, albeit with untreated, acidic wastewater, resulted in negative results. It was also noted that Alternative \#1 required that less material be delivered over the poor local road.

\section{SPONSORSHIP FUNDING AND OVERSIGHT}

In order to support completion of the project, the Seattle University Project Center sought external funding for the design of the water treatment facility, the construction of the beneficio and water treatment facility, and the international travel required. An environmental engineering firm, Tetra Tech, expressed interest in the project and issued a request for proposal in September 2007, which resulted in project funding in November 2007.

The project team visited La Suana and the model farm La Canavalia in December 2007, and the design project was carried out in January - May 2008. After the community at La Suana selected Alternative 1, it became the subject of a written agreement facilitated by the agricultural engineer from CRS-NI and the engineers and contractors of CECOSEMAC who would provide for construction and project oversight. The agreement was signed by the president of CECOSEMAC and the project principal, Professor Susan Jackels of Seattle University.

The project and accompanying budget was divided into three phases. A report and photographs of each completed phase would be submitted by email in order to qualify for disbursement of funds for the next phase. Communication by email served to answer questions and respond to changing conditions, the most significant being that labor costs were higher than anticipated. These increased costs necessitated an adjustment in the design (omission of the fill rocks in the water treatment pits), so that the project could remain within budget. 


\section{FinAl INSPECTION AND OVERALL ASSESSMENT}

In December 2008, three of the faculty team members visited the completed beneficio and water treatment facility at La Suana. Although the coffee harvest at the altitude of La Suana had not yet started, the farmers did find a small sample of cherries in order to demonstrate the operation of the beneficio. The beneficio itself was fully functional and built to high quality standards (see

Figure

8).

The community had made some "modifications" to the proposed wastewater treatment plan, however. The four basins had been dug to specifications and connected properly with PVC piping. Instead of the primary settling basin being lined with a plastic sheet as specified and the three infiltration pits being unlined, all four excavations had unlined bottoms with walls constructed from bricks and mortar (Figure 9). While this change seemed like an improvement to the community, the unlined settling pit rendered it just another infiltration pit, and the impermeable walls decrease the infiltration rate from the pits to the soil.

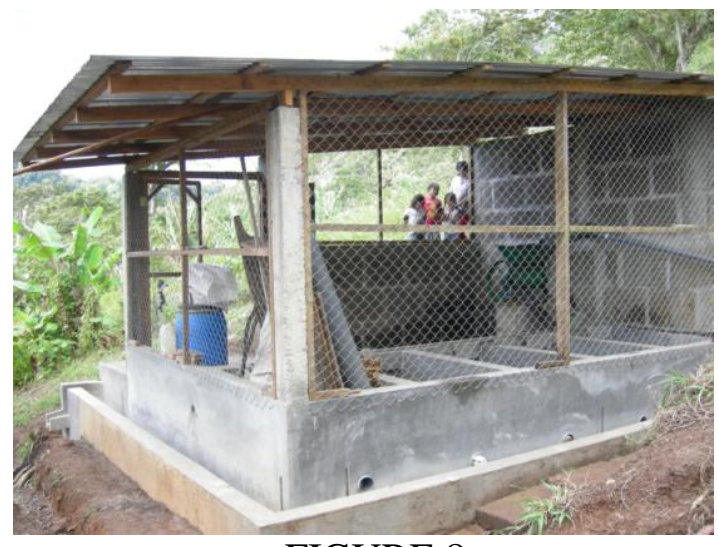

FIGURE 8

BENEFICIO AT LA SUANA

In order to reduce the cost of delivering supplies and because of a community concern about the infiltration pit volumes not being adequate with the gravel in place, the community chose not to fill the pits with gravel, thus significantly affecting the rate at which they are expected to reduce BOD. This is an example of the client trusting what could be seen (the larger volumes of unfilled pits) rather than what had been carefully calculated. When informed of this community decision, it was deemed acceptable by the team leader (MDM) with the knowledge that it could be reversed at any time by adding gravel to the pits. 


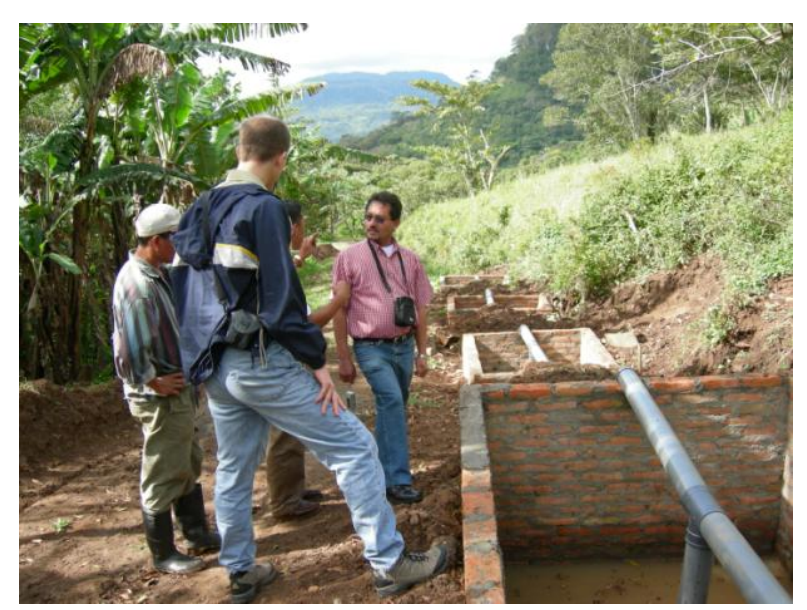

FIGURE 9

SETTLING BASIN (FOREGROUND) AND INFLITRATION PITS AT LA SUANA

One unexpected result of this effort was that, upon hearing of the foreign investment in the community, the local government decided to improve the road to La Suana in order to facilitate the beneficio construction. This allowed trucks to get close to the site, greatly facilitating materials delivery. The community viewed the road improvement as being more valuable than the beneficio itself, since the improved road served approximately 100 farms year around.

Additional funding for travel and construction cost overruns would have been most helpful to the overall project. The presentation of the designs and the recommendation favoring Alternative \#2 might have been more effective if the team leadership had visited La Suana in April or May 2008. A visit during construction of the wastewater treatment facility might have led to an implementation in closer compliance with the original design. The costs of construction of the beneficio itself turned out to be somewhat higher than originally predicted, and the lack of sufficient funding for cost overruns made the community more conservative when considering the cost of the wastewater treatment facility.

From a technical and development point of view, the project was quite successful. The poor community at La Suana obtained a state-of-the-art beneficio and a wastewater treatment facility that is an improvement upon the general practice in their region.

From a service learning point of view, the project was an unqualified success. A team of engineering students put their capstone design project into direct service to a poor community in the developing world. These students traveled to Nicaragua, interviewed the clients, and designed options for them that were technically sound, of appropriate technology and culturally acceptable. The students also saw their design actually built and implemented. They learned the importance of effective communication with clients across language, economic, and cultural barriers and gained experience working as a multi-disciplinary team of engineers, scientists, officials of international development organizations, and small community leaders. 
International Journal for Service Learning in Engineering

Vol. 7, No. 1, pp. 69-92, Spring 2012

ISSN 1555-9033

The team leadership has been approached about replicating this project with another small community in Nicaragua. With lessons learned from our initial project, we are enthusiastically searching for sponsorship of a second one.

\section{ACKNOWLEDGEMENTS}

The team thanks the Tetra Tech liaisons, Grizelda Sarria and John Markus, for their consistent and excellent help and guidance throughout the project. The team also thanks Professor Jeff Dragovich of Seattle University and his students, while in Nicaragua for another project, for providing a preliminary survey of the La Suana site during spring 2007. 
International Journal for Service Learning in Engineering Vol. 7, No. 1, pp. 69-92, Spring 2012

ISSN 1555-9033

\section{REFERENCES}

${ }^{1}$ ICO 2011. Composite Indicator Price 2011, International Coffee Organization, London. Available at http://www.ico.org/coffee-prices.asp. Accessed on August 19, 2011.

${ }^{2}$ Mohan S, Russel B, "Modelling thirty five years of coffee prices in Brazil, Guatemala and India."” Dundee Discussion Papers in Economics, University of Dundee, Scotland. Number 221, December 2008.

${ }^{3}$ Oxfam International 2003. "Mugged: Poverty in your coffee cup." Oxford, UK: Oxfam Publishing, Nov 2003, 58 p.

${ }^{4}$ Cup of Excellence Program 2011. Nicaraguan Programs. Available 25Aug2011:

http://www.cupofexcellence.org/CountryPrograms/Nicaragua/tabid/62/Default.aspx

${ }^{5}$ USAID, see for example "Combatting the Coffee Crisis with Quality Products", a report on the Nicaraguan component of the program. United States Agency for International Deveopment, Washington DC 2009. Available at:

http://www.usaid.gov/stories/nicaragua/fp nicaragua coffee.html. Accessed on August 19, 2011.

${ }^{6}$ Bacon CM, Mendez VE, Flores Gomez, ME, Stuart D, Diaz Flores SR, "Are sustainable coffee certifications enough to secure farmer

Livelihoods? The millennium development goals and Nicaragua's Fair Trade cooperatives." Globalizations 2008; 5(2): 259-274.

${ }^{7}$ Valkila J. "Fair Trade organic coffee production in Nicaragua - Sustainable development or a poverty trap? " Ecological Economics 2009; 68: 3018-3025.

${ }^{8}$ Utting-Chamorro K. "Does Fair Trade make a difference? The case of small coffee producers in Nicaragua."“ Dev. In Pract 2005; 15 (3\&4): 584-599.

${ }^{9}$ Author Listing Removed "Coffee for Justice: Chemistry and Engineering in Service to the Jesuit Mission with Small-holder Coffee Farmers of Nicaragua."' Revised and accepted for publication in "Justice in Higher Education, Transforming the World and Being Transformed," to be published by Fordham University Press, 2012.

${ }^{10}$ Author Listing Removed. "Characterization of the Coffee Mucilage Fermenation Process using Chemical Indicators: A Field Study in Nicaragua", J. Food Science 2005.70: C321-5,

${ }^{11}$ Author Listing Removed. "Control of the Coffee Fermenation Process and Quality of Resulting roasted coffee: Studies in the Field Laboratory and on Small Farms in Nicaragua during the 2005-06 Harvest.", Proceedings of the $21^{\text {st }}$ ASIC (Association Scientifique Internationale du Café)

Meeting (Montpelier) 2006, pp. $434-442$.

${ }^{12}$ Sas M. "Contamination potential of coffee processing 2006/2007.” Managua (Nicaragua):Ministerio Agropecuario y Forestal (MAGFOR) May 2007. 22p. Available 25August 2011:

http://www.waterharmonica.nl/matagalpa/publicaties/evaluation_document_cp_marco_sas_nunio_2007.pdf

${ }^{13}$ Sas MJ. "Eco-engineered treatement of coffee wastewater according to the waterhamonica: A case study in Matagalpa, Nicaragua."

Wageningen (Netherlands): Aqua for All \& LEAF May 2006. 53 p. Available 25 August 2011: http://hbo-

kennisbank.uvt.nl/cgi/hz/show.cgi?fid=758

${ }^{14}$ USDA. "What does the organic label really mean?" US Department of Agriculture. Available 25 August 2011: http://usda-

fda.com/articles/organic.htm

${ }^{15}$ FairTrade 2011. "Generic Fair Trade standard for small producer organizations." Bonn: Fair Trade International August 2011. Available

25August2011: http://www.fairtrade.net/654.0.html

${ }^{16}$ Author Listing Removed., "Wastewater Treatment Design for a Coffee Processing Beneficio: Project Report to TetraTech Inc." Science and Engineering Project Center, (Removed) University, Report CEE 08.4, 2008.

${ }^{17}$ NRCS, “Carribbean Area Online Soil Manuscripts." Published by Natural Resources Conservation Service, United States Department of Agriculture, Washington DC. Available November at: http://soils.usda.gov/survey/online_surveys/caribbean/. Accessed 27 Nov2011.

${ }^{18}$ USDA 1975, "Soil Survey of Mayaguez Area of Western Puerto Rico." Soil Conservation Service, U.S. Department of Agriculture, 1975. See Table 5, pp 200-201 for Aibonito data.

Available: http://soildatamart.nrcs.usda.gov/manuscripts/PR684/0/Mayaguez.pdf. Accessed 27 Nov 2011.

${ }^{19}$ USDA 1979, "Soil Survey of Ponce Area of Southern Puerto Rico." Soil Conservation Service, U.S. Department of Agriculture, 1979. See Table 7, pp 60-63 for Cortada data and Lirios data.

Available: http://soildatamart.nrcs.usda.gov/manuscripts/PR688/0/Ponce.pdf. Accessed 27 Nov 2011.

${ }^{20}$ MARENA 1995. Ministerio del Ambiente y los Recursos Naturales de Nicaragua. Publised in: La Gaceta diario official, Decreto No. 33-95, Arto 38, Gobierno de la Republica de Nicaragua, Managua, Nicragua, 1995.

${ }^{21}$ Deepa GB, Chanakya HN, de Alwis AAP, Manjunath GR, and Finutha D. "Overcoming pollution of lakes and water bodies due to coffee pulping activities with appropriate technology solutions". Proceedings of Lake 2002: Conservation, Restoration and Management of Aquatic Ecosystems, December 2002, Bangalore, Session 10, Paper 4.

${ }_{22}$ Metcalf and Eddy Inc, Tchobanoglous G, Burton F, Stensel HD. "Wastewater Engineering: Treatment and Reuse", $4{ }^{\text {th }}$ ed. McGraw Hill (Boston, 2003). 1819 p.

${ }^{23}$ Brady N and Weil R., "The Nature and Properties of Soils." $13^{\text {th }}$ Ed, Prentice Hall,( Upper Saddle River, NJ, 1999) 960p.

${ }^{24}$ Eckenfelder WW.. "Industrial Water Pollution Control", $3^{\text {rd }}$ Edition.. McGraw Hill (New York) 1999. 584 p.

${ }^{25}$ WHO 2007. 'Technical Consultation on Specifications and Quality Control of Netting Materials and Mosquito Nets: Updated WHO specifications for netting materials and mosquito nets. World Health Organization (Geneva) 2007, 28 p.

${ }^{26}$ Bidlingmayer, WL. "Mosquito Penetration Tests With Louver Screening”, The Florida Entomologist, 1959:42(2):63-67

${ }^{27}$ King County, WA. Flow Control Design. Chapter 5 of Surface Water Design Manual, 2005. King County, Washington(Seattle) 2005.528 p. Available from King County:

http://your.kingcounty.gov/dnrp/library/archive-documents/wlr/dss/2005SWDM/2005ManualwithErrata.pdf. Accessed on 9 Dec 2011.

${ }^{28}$ EPA 1993. "Subsurface flow constructed wetlands for waste water treatment." Washington: US EPA 832-R-93-008, July 1993. 87 p. Available: www.epa.gov/owow/wetlands/pdf/sub.pdf.

${ }^{29}$ Tommaso G, Varesche MB, Zaiat M, Foresti E, Ribeiro R. "Influence of multiple substrates on anaerobic protein degradation in a packed-bed bioreactor." Water Science and Tech 2003: 48(6): .21-23.

${ }^{30}$ Gohill, MB. Land Treatment of Wastewater, New Age International(New Dehli), 2000, 134p. 
${ }^{31}$ EPA 1981, “Process Deisgn Manual for Land Treatment of Municipal Wastewater”, Report No 625/1-81-013, United States Environmental Protection Agency, Washington DC, October 1981, 477p.

${ }^{32}$ Cozzarelli I, Bekins B, Eganhouse RP, Warren E, Essaid H. "Measurement of Hydrocarbon Biodegradation Rates Using In Situ Techniques." Abstract 213-11, 2005 Salt Lake City Annual Meeting of the Geologic Society of America 2005. Available:

http://rock.geosociety.org/meetings/searchabstracts.htm.

${ }^{33}$ Davis ML and Cornwell DA, "Introduction to Environmental Engineering:, $4^{\text {th }}$ ed, McGraw-Hill (New York 2006), 1024p.

${ }^{34}$ EPA 1984, "Process Deisgn Manual for Land Treatment of Municipal Wastewater: Supplement on Rapid Infiltration and Overland Flow", Report No 625/1-81-013a, United States Environmental Protection Agency, Washington DC, October 1984, 132p.

${ }^{35}$ Crites R and Tchobanoglous G. "Small and Decentralized Wastewater Management Systems. "McGraw Hill (New York), 1998.1084 p.

${ }^{36}$ Havlin JL, Tisdale SL, Nelson WL, and Beaton JD. "Soil Fertility and Fertilizers: An Introduction to Nutrient Management", $7^{\text {th }}$ ed. Prentice Hall (Upper Saddle River, NJ), 2004. 528p.

${ }^{37}$ Washington State Department of Ecology. Water Quality Standards for Ground Waters for the State of Washington. Chapter 173-200 WAC,

Table I. State of Washington, Olympia (1990). Available: http://www.ecy.wa.gov/pubs/wac173200.pdf 